特集 $*$ 最近のコンクリート用混和剤 $/ 2.7$

\title{
収縮 低 減剂
}

\section{富 田 六 郎*}

\section{1.まえがき}

コンクリートの乾燥收縮量の予測は多くの研究者によ り試みられており，ある程度までは可能であるが，これ を大幅に減らすことは技術的, 経済的にもむずかしい課 題である。さらに, 乾燥收縮に伴って発生するひびわれ が耐久性, 水密性, 美観上の障害を引き起こす抢それが あるため, 乾燥収縮はコンクリートの根本的な問題とし て常にクローズアップされている。

乾燥収縮を低減する手段は多く考えられ，その中で混 和材料の使用が種々試みられ実用化されてきている。単 位水量を減少できる減水剤や流動化剂も, 間接的ながら 乾燥収縮を低減しうる一種の収縮低減剤である。しか し, ここでは, 近年開発・市販されている, 主に乾燥収 縮の低減だけを混和剤の機能としてもつ有機系の材料を 收縮低減剤として取り上げ，説明を加えることとする。

これらは実用化後 10 年にも満たない新規な材料であ り, 用語の定義もまだ定かではない。このため, 収縮低 減機構の理論的な解明も十分ではなく, 具体的かつ効果 的な利用法に関する資料も十分に整えられていない。ま た, コストに代表される種々の問題もあり, 今後改善さ れるべき点も多いと思われる。しかし, 収縮ひびわれに 対する効果は認識されてきており, 他の混和材料との併
用で特色のあるコンクリートを得るなど，応用分野は広 がりつつある。

ここでは，収縮低減剤を用いたコンクリートについ て，その特徴的な点を中心にとりまとめた。

\section{2. 収縮低減剤の化学・物理的性質}

\section{1 収縮低減剤の種類}

現在, 組成の異なる 4 種類の収縮低減剤が市販されて いる。これらを表一1 にとりまとめて示した。このう ち, 3 種は空気を連行する通常の $\mathrm{AE}$ 減水コンクリー 卜に適用することを原則としているのに対し, 消泡性を もつ 1 種は空気非連行タイプのコンクリートとして用い られる。また，コンクリート用混和剤としてではなく， 硬化後のコンクリートに表面から含浸させることによっ て乾燥収縮を抑制する利用法も実用化されている。

\section{2 化学組成}

乾燥収縮低減機能をむつ薬剤は, 広沉に存在すること が認められている。しかし, 表一1 に示す市販品 4 種は 類似したタイプのものである。主成分を表中に提示した が, 組成を一般式で表示すると $\mathrm{R}_{1} \mathrm{O}(\mathrm{AO}) n \mathrm{R}_{2}$ となる。 ここで, 骨格となるAは炭素数 $2 \sim 4$ 程度のアルキレン 基で， 2 種の異なるアルキレン基を順次あるいはランダ ムに重合させたものもある。 $n$ は重合度を示す整数で,

表-1 市販の収縮低減阂の物性

\begin{tabular}{|c|c|c|c|c|c|c|c|c|c|c|}
\hline $\begin{array}{l}\text { 記 } \\
\text { 号 }\end{array}$ & 主 & 成 & 外 & 比重 & $\begin{array}{l}\text { 粘 度*1 } \\
(\mathrm{cps})\end{array}$ & $\mathrm{pH}^{* 2}$ & $\begin{array}{l}\text { 表面張力*3 } \\
(\text { dyn } / \mathrm{cm})\end{array}$ & 溶 & 解 性 & 標準使用量 \\
\hline A & $\begin{array}{l}\text { 低級アル } \\
\text { アルキ }\end{array}$ & $\begin{array}{l}\text { ール } \\
\text { ンオキンド付加物 }\end{array}$ & 無色透明液体 & 0.98 & 16 & $6 \pm 1$ & 41.9 & & 溶 性 & $\begin{array}{l}12 \mathrm{~kg} / \mathrm{m}^{3} \\
(C \times 4 \%)\end{array}$ \\
\hline $\mathrm{B}$ & $\begin{array}{l}\text { 低級アル } \\
\text { アルキ }\end{array}$ & $\begin{array}{l}\text { ール } \\
\text { ンオキンド付加物 }\end{array}$ & 青色透明液体 & 1.00 & 約 20 & 6 & 29.6 & 易 & 溶 性 & $\begin{array}{c}7.5 \mathrm{~kg} / \mathrm{m}^{3} \\
(C \times 2.5 \%)\end{array}$ \\
\hline $\mathrm{C}$ & ポリエ & $\bar{J}$ & 無色～淡色液体 & 1.02 & $100 \pm 20$ & $7 \pm 1$ & 39.5 & 易 & 溶 性 & $C \times 2 \sim 6 \%$ \\
\hline $\mathrm{D}$ & ポリタリ & $-ル$. & 淡黄色液体 & 1.04 & 50 & $6 \pm 1$ & 33.5 & 難 & 溶 性 & $C \times 1 \sim 4 \%$ \\
\hline
\end{tabular}

*1 $20^{\circ} \mathrm{C}$ ての值 $\quad * 2 \mathrm{~A} \sim \mathrm{C}$ は $1 \%$ 水溶液, Dは水・メタノール混合液に $1 \%$ 溶解した值

*3 収縮低減䬉をセメントの $2 \%$ 混合したモルタルの上澄液の值 $\left(20^{\circ} \mathrm{C}\right.$, 試験值)

*とみた・ろくろう/日本セメント侏中央研究所主任研究員補 (正会員) 


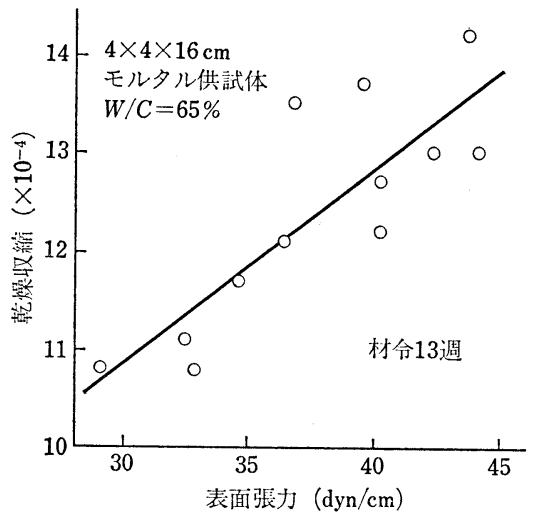

図-1 表面張力と乾燥収縮の関係 ${ }^{3)}$

一般には 2〜5 程度だが，10 以上の大きな分子量の組 成物も低減機能をもつ。 $\mathrm{R}$ は水素基, アルキル基, シク ロアルキル基，フェニル基等である。

一般には，重合，付加，精製の過程を経て工業的に製 造される合成物質であり, 重合度の異なる各種物質があ る幅をもって分布した複合体である。

\section{3 物理的性質}

4 種とも組成物そのものが液体の混和剤であり, 水と 同じコンシステンシー増大作用をもっている。また，比 重も約 1 であるため, 単位水量の一部に置き換えて使用 することを原則としている。

粘度は水と比べてかなり高く, また, 液相の表面張力 を大幅に低減する機能をもっている。表面張力がコンク リートの乾燥収縮と関連性をもつことは複数の研究者に よって論じられてきており, この種の収縮低減剤を用い た場合にも表面張力と乾燥收縮を関連づけた報告があ $3^{11,2)}$ 。したがって，この低下量が収縮低減効果を評価 するうえでの目安になると考えてよい。図一1 はモルタ ルの乾燥収縮と沪液の表面張力の関係を示したものであ るが，類似した組成の収縮低減剤であれば，両者には高 い相関性が存在する。

使用量が比較的多く, 混和剤の定義を逸脱するようで あるが, 液体のイメージから, 混和材ではなく混和剤と みなしている。標準使用量は経済性をも考慮した量であ って, ひびわれの防止を目的とするのか, 有害なひびわ れの制御を目的とするのか, あるいは他の材料との複合 効果を目的とするのか等によって適切な量を選択でき る。当然のことながら, 使用量を増すことで, より大き い収縮低減効果を得ることができる。

3. コンクリートの物性

\section{1 乾 燥収縮}

4 種の収縮低隇剤を用いた結果の例を図一2 に示す。

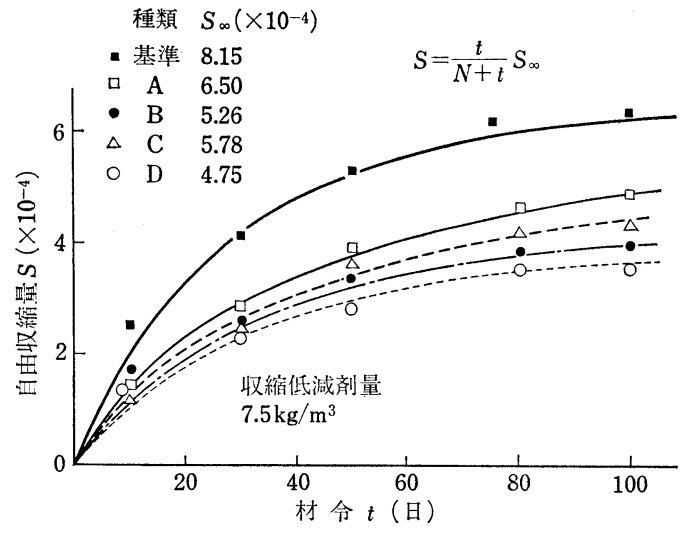

图一2 自由収縮量に及ぼす低減剤の影響出)

混和剤ごとに差はあるものの, 推定した終局值は基準と なる $\mathrm{AE}$ コンクリートの $60 \sim 80 \%$ となり，明らかに 乾燥収縮を減らす効果が認められる。また, 収縮低減効 果は使用量によって変わり, 収縮低減剤の単位使用量に ほぼ比例することが確かめられている5゙。

そこで, 多数のデータを基に収縮低減剤量のほかに単 位水量と単位膨張材量を説明因子として重回帰分析した 材令 26 週の乾燥收縮の推定式を例示すると下式のよう である5)。

$$
D S_{26}=390.4+2.89 \mathrm{~W}-21.77 A-4.758 \mathrm{E}\left(\times 10^{-6}\right)
$$

ここで, $W$ : 単位水量 $\left(\mathrm{kg} / \mathrm{m}^{3}\right), A:$ 収縮低減剤 $\mathrm{A} の$ 量 $\left(\mathrm{kg} / \mathrm{m}^{3}\right), E$ : 単位膨張材量 $\left(\mathrm{kg} / \mathrm{m}^{3}\right)$

収縮低減剤 $\mathrm{A}$. $10 \mathrm{~kg} / \mathrm{m}^{3}$ 水に置き換えたときの収縮 低減量 $(2.89 \times(-10)-21.77 \times 10=-247)$ を単に単位 水量の減少だけで得るためには, この式からは約 $80 \mathrm{~kg} /$ $\mathrm{m}^{3}(247 \div 2.89)$ の単位水量を 減らさなければならない こととなる。このように, 収縮低減剤を適量使用するこ とで, 配合条件の変更だけでは得ることのできない比較 的大きな収縮低減効果を期待できる。

また, 同一条件の基準コンクリートに対する収縮低減 剤を混入したコンクリートの収縮比は，コンクリートの 配合条件によらず，単位使用量と良い相関を示すと言わ れている5)。図-3 は, 2 種の収縮低減剤について両者 の関連を示したものであるが，全体としては直線関係に 近い相関がみられる。収縮低減剤の種類によって効果に は違いがみられ，収縮比を $60 \%$ とする使用量を直線回 州式から算出すると, A で約 $12 \mathrm{~kg} / \mathrm{m}^{3}$ であるのに対 し, Bでは約 $6 \mathrm{~kg} / \mathrm{m}^{3}$ であり, 半分の量で同等の効果 が得られている。

以上の結果は, 一定の乾燥条件を継続した場合の乾燥 収縮值であり, 潜在する収縮能力を表すむのと考えられ る。これに対し, 実際にコンクリートがさらされる環境 は, 雨水等による乾湿の繰返しや温度変化があり, 恒温 


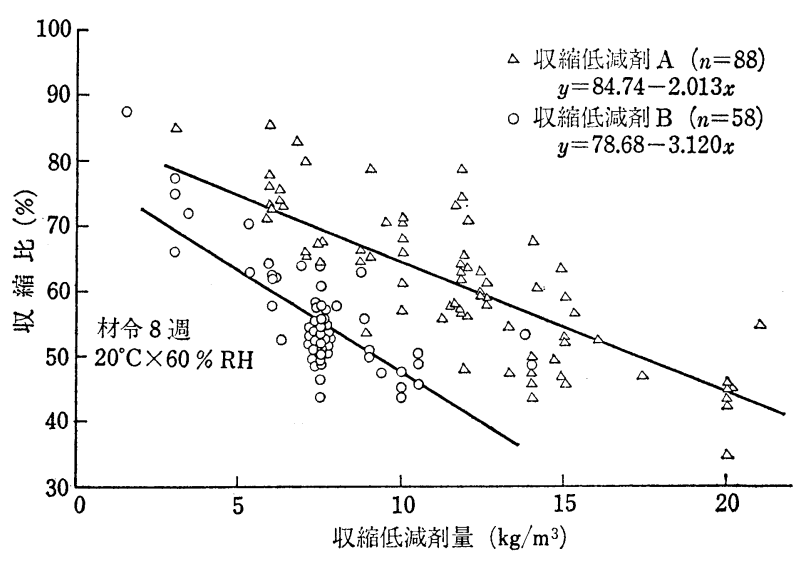

図一3 収縮低減剤量と乾燥収縮の低減効果

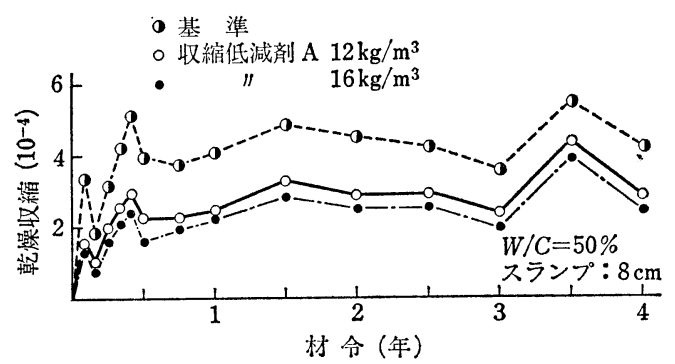

図-4 屋外におけるコンクリートの長さ変化

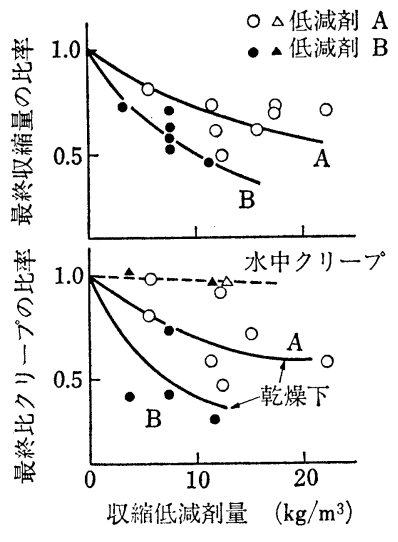

図一5 コンクリートのクリープ6)

恒湿下とは条件が異なる。このような屋外の条件に長期 間暴露した場合の温度補正後の長さ変化を図一 4 に示 す。収縮量は一定の乾燥条件とした場合の約半分程度と なり, また, 外気の温・湿度の影響を大きく受けながら も，長期間にわたって収縮低減効果を維持することが認 められる。

\section{2 一般的な物性}

硬化コンクリートの物性は, 同一配合条件で収縮低減 剂を用いないものとほとんど同等の性能が得られると考
えてよい。乾燥収縮のほかに特徵的な点は，第一 には，図一5に示すように乾燥条件下に扔けるク リープが大幅に減少することである。水中でのク リープが収縮低減剤の混和にかかわらず一定であ るのに対し，乾燥下では乾燥収縮と同程度にクリ ープが減少しており，両者が類似した機構で説明 できるものであることを示唆している。第二は凍 結融解抵抗性であるが，この点については後で説 明する。

基本的な物性である圧縮強度は, 通常のコンク リートと同様に水セメント比に支配され，収縮低 減剤を水とみなせば，同一水セメント比で収縮低 減剤使用の有無による強度に大きな違いはない。

図一6 は練りまぜ，養生の温度を $5 \sim 20^{\circ} \mathrm{C} に$ 変えたときの圧縮強度の発現性を示した例である。全体 にわたって，同一水セメント比，同一空気量の基準コン クリートとほぼ同等の強度発現性を発揮すると言える。

長期的な強度性状についてもほぼ同様のことが言え, 乾燥を受ける養生条件下では, むしろ収縮低減剤を混和 していることが強度面で有利作用すると考えられる。

4.ひびわれに対する効果

\section{1 抱拘ひびわれ試験}

收縮低減剤のひびわれに対する効果を定量的に評価し た例はみられないが，実験室的に相対的に評価した報告

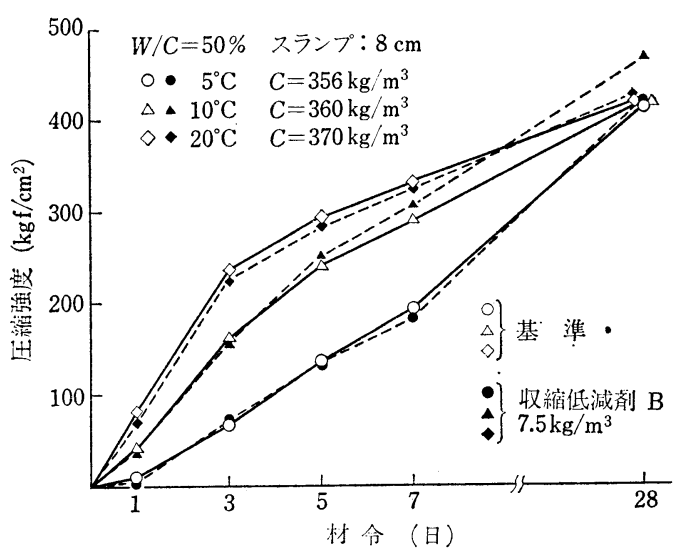

図一6 養生温度が異なった場合の初期の強度発現性

表一2 ひびわれ試験の概要》

\begin{tabular}{|c|c|c|c|c|c|}
\hline No. & 種 類 & $\begin{array}{c}\text { スランプ } \\
(\mathrm{cm})\end{array}$ & $\begin{array}{l}\text { 戦位水量 } \\
\left(\mathrm{kg} / \mathrm{m}^{3}\right)\end{array}$ & 混 和 剂 & $\begin{array}{l}\text { 貫通ひびわれ } \\
\text { 生日) }\end{array}$ \\
\hline (1) & 基 準 & 18 & 170 & $\mathrm{AE}$ 減 水剂 & 29 \\
\hline (2) & 軟練り & 21 & 185 & $\mathrm{AE}$ 剂 & 29 \\
\hline (3) & 硬練り & $12 \rightarrow 18$ & 158 & 流 動 化 剂 & 32 \\
\hline (4) & 低減剂 & 18 & 170 & $7.5 \mathrm{~kg} / \mathrm{m}^{3}(\mathrm{~B})$ & * \\
\hline
\end{tabular}

*.材令 100 日でなし 


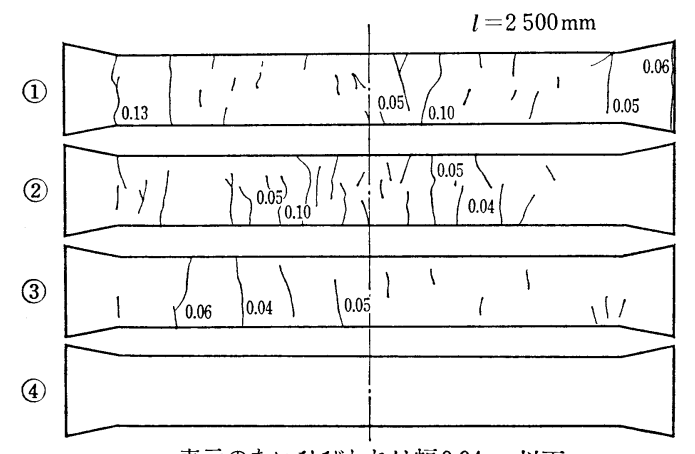

表示のないひびわれは幅 $0.04 \mathrm{~mm} 以 下$

図-7 ひびわれの発生状況 ${ }^{7)}$

は多くみられる。

剛性フレームで拘束した R C 供試体を用い，収縮低減 剤を含めてコンクリートの配合等の影響を検討した報告 によれば, 収縮低減剤のひびわれ防止効果は他の方法と 比べて著しく高いことが示されている。表一2 および図 -7 はその効果の概要であるが，コンクリートの硬練り 化等では得ることのできない顕著な効果の得られること が分かる。

\section{2 実構造物での効果}

実構造において，内部ひずみの測定と併せてひびわれ

\section{表一3 コンクリートの配合条件 ${ }^{8)}$}

\begin{tabular}{|c|c|c|c|c|}
\hline 階 & 数 & $\begin{array}{c}\text { コンクリートの仕様 } \\
\sigma_{c}-\mathrm{S} l .-G_{\max }\end{array}$ & $\begin{array}{l}\text { 単位水量 } \\
\left(\mathrm{kg} / \mathrm{m}^{3}\right)\end{array}$ & $\begin{array}{c}\text { 混 和 材 料* } \\
\left(\mathrm{kg} / \mathrm{m}^{3}\right)\end{array}$ \\
\hline 地 & 階 & $240-18-20$ & 192 & $\begin{array}{l}\text { 膨 張 材 } 30 \\
\text { 収縮低隇绪 } 13.96\end{array}$ \\
\hline 1 & 階 & $240-18-20$ & 192 & - \\
\hline 2 & 階 & $240-12-20$ & 176 & 流動 化剂 1.60 \\
\hline 3 & 階 & $210-18-20$ & 190 & 收縮低減䬉 12.68 \\
\hline 4 & 階 & $210-18-20$ & 190 & $\begin{array}{l}\text { 膨 張 材 } 30 \\
\text { 収縮低減剂 } 12.68\end{array}$ \\
\hline 5 & 階 & $210-12-20$ & 175 & 流動 化 剂 1.46 \\
\hline
\end{tabular}

*いずれも $\mathrm{AE}$ 減水剤を使用している。収縮低減剤はA $\mathrm{A}$ を使用。
観察を行い, 収縮低減剤の効果を評価した報告は数例み られる。そして, そのいずれもが, 収縮性のひびわれに 対して十分な効果を発揮すると報告している。

$\mathrm{R} \mathrm{C}$ 造建築物に適用し, 外壁の開口部周辺のひびわれ 状況を観察した報告によると, 収縮低減剤を用いた部位 あるいはこれと膨張材を併用した部位では，ひびわれは ほぼ防止されて抒り，標淮的な $\mathrm{AE}$ 減水コンクリート や流動化コンクリートと対比して優れた性能を発揮して いる。表一3 は, 対比したコンクリートの配合条件であ り,ひびわれ観察結果の一部を図ー8 に示した。

\section{5 ． 使用上の留意点}

\section{1 概 要}

市販の収縮低減剤はそれぞれに特徴をもっているた め，すべてを一般化して述べることはできないが，コン クリート用混和剤として使用するに際して注意が必要な 主な留意点は以下のようである。

1）空気連行性が不安定, あるいは空気連行が不可能

2）上に関連して凍結融解抵抗性が低下寸る

3） 相性の悪い混和材料がある

4）コスト高になる（2000 8 000 円 $/ \mathrm{m}^{3}$ 程度のコス トアップ)

上記各項目の詳細な説明は誌面の都合で他の機会に譲 るが, これらのうち, 解明の進んでいる凍結融解抵抗性 について説明を加えてみる。

\section{2 凍結融解抵抗性}

收縮低減剤を用いたコンクリートは，水の物性の変化 や気泡組織の变化に起因して凍結融解抵抗性が低下し, ASTM 法（急速水中試験）で評価すると耐久性を示さ ない。しかし，以下のような点から，実用上十分に耐久 的なコンクリートが得られると考えられている。

収縮低減剤Aを用い，14 日間の水中養生後に ASTM 法（急速水中凍結試験）で 300 サイクルの凍結融解を 行った結果を図一9 に示す。空気量を 4〜5\% 以上とす

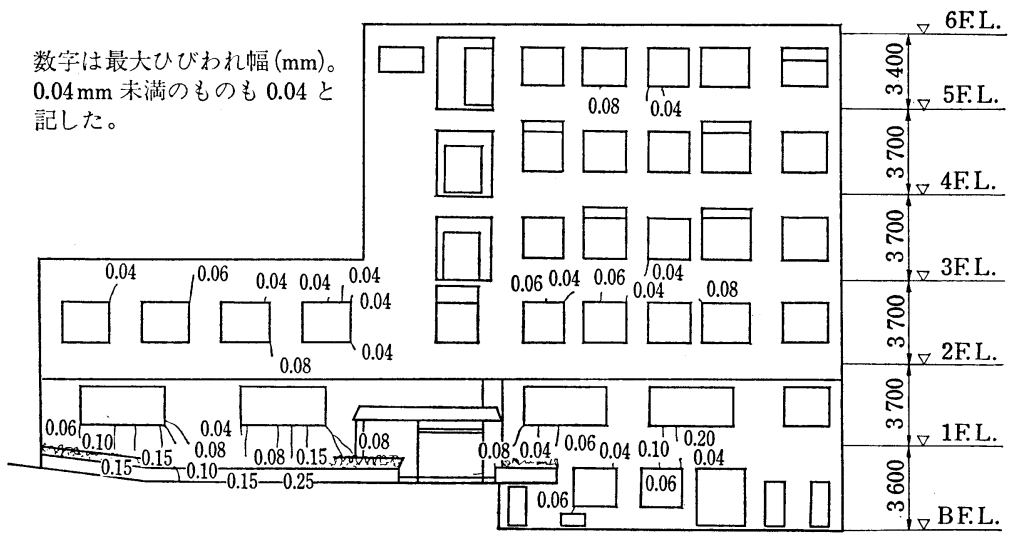

図一8 打込みから 2 年半経過後の仕上げタイル面のひびわれる 


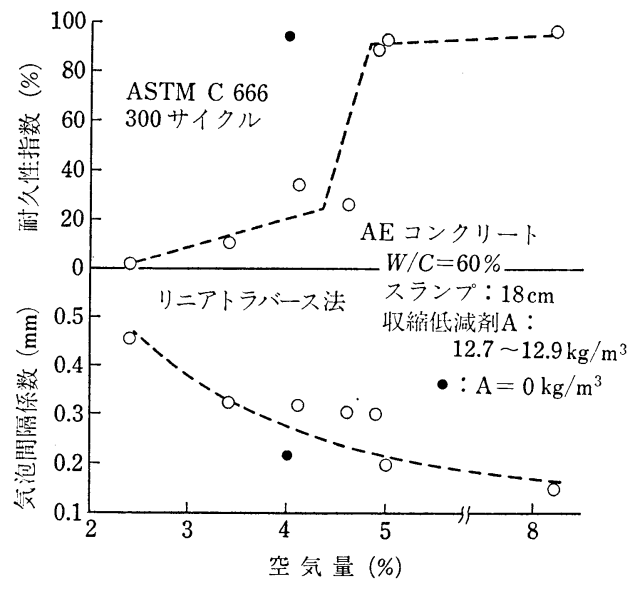

図一9 空気量と耐久性との関係

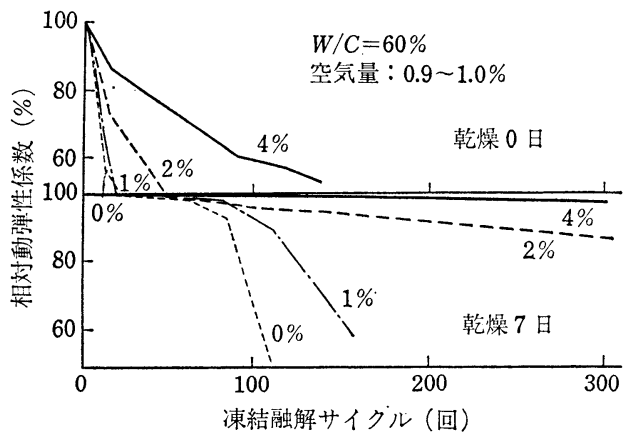

図一10 乾燥条件と耐久性との関連 ${ }^{93}$

ると耐久的なコンクリートが得られており，通常のコン クリートよりも 1 2\% 大きい空気量が必要なことを示 している。図一8 中に示した気泡間隔係数を比較して も，収縮低減剤を用いた場合，同一の值とするには若干 空気量を大きくする必要のあることが分かる。

図一10は, 空気非連行タイプの収縮低減剤Dの試験 結果である。養生期間中にコンクリートをわずかに乾燥 させると, 混和量の多い配合条件で耐久性が向上するこ とを示している。この理由は完全には明らかにされてい ないが，分散して存在する微少な収縮低減剤の塊によ り，見かけ上，気泡間隔係数が低下していることに関連 づけた説明がなされている。いずれにしても, 実際の構 造物が必ずある程度の乾燥を受けることを考えると，実 用上耐久性に問題のないコンクリートが得られると結論 づけている。

収縮低減剂Bについても, 凍結速度や乾燥程度が凍結 融解抵抗性に深く関与していることが認められており， 積雪寒冷地に数年間暴露したコンクリート供試体の試験 結果からも, 耐久的なコンクリートの得られることが確 かめられている。

Vol. 26, No. 3, March 1988

\section{6. 複合効果}

\section{1 膨張材との併用}

無機系の膨張材は, 単独でもひびわれ防止に対して有 効であることが認められている。そして, 収縮低減剤と 膨張材を同時にコンクリートに混和しても，お互いの性 能が何ら損なわれることはない。

双方を併用したコンクリートを構造物に適用すると， 膨張材はかぶりの外側等の拘束の弱い部分では自由膨張 に近くなって有効ではないが，十分に拘束した部分で効 果的に作用し, 収縮低減剤は逆に拘束の弱い部分で効果 的に作用するというように，お互いが弱点を補い合って 構造物全体としてのひびわれ抑止に寄与する。

また，両者の併用で無収縮のコンクリートとすること も可能である。建築物の壁体に利用した例では，1 年を 経過した時点においてもひずみは膨張側にあり, その結 果, 十分なひびわれ防止効果が得られたと報告されてい る10)。

\section{2 その他の材料との複合}

炭酸ガスや塩素イオンと反応し, これら有害物のコン クリート内部への浸透を防ぐことのできるアミノアルコ ール系の混和剤を空気非連行タイプの収縮低減剤と組み 合わせることで, 高度の中性化抑止機能と塩素イオン浸 透阻止機能をもった収縮ひびわれ防止機能の高いコンク リートを得ることができる。このような組合せ効果によ って非常に高い耐久性が得られるとの結果が示されてい る $^{11)}$ 。

また，各種繊維類との複合や樹脂系材料との併用とい った試みもなされているが，まだ実用化には至っていな い122。基本的には，あらゆる材料と複合させても，それ ぞれの特徴を累加的に発揮できると考えられる。

\section{7.あとがき}

収縮低減剤について特徵的な性質を中心にとりまとめ たが，限りのある誌面で十分に意を尽くしきれない点も 残っている。また，現象面からだけの議論に終始し，説 明に説得力が欠けることも否めない。

材料の改良を含めた問題点の解明は今後も続けられて いくと考えるが, 将来の方向性, 展開について読者諸氏 のご教示を頂ければ幸いである。

<参考文献〉

1）長滝重義・米倉亜州夫 : コンクリートの 乾燥收縮 および クリープの機構関する考察, コンクリート工学, Vol. 20, No. 12 , 昭 57.12

2）佐藤 健・後藤孝治・酒井公式：セメント硬化体の 乾燥 収縮を低減する有機質混和剂の作用機構，セメント技術 年報, Vol. 37, 昭 58

3）富田六郎・後藤孝治・茂庭孝司・酒井公式 : 収縮低 減成 を用いたコンクリートの乾燥収縮およびひびわれに関す 
る実験研究, 第 5 回コンクリート工学年次講演会 講演論 文集, 昭 58

4）庄谷征美・杉田修一・菅原 隆：混和剤によるコンクリ ートの收縮ひびわれ低減に関する 2,3 の実験, 土木学 会第 42 回年次学術講演会, V, 昭 62.9

5）富田六郎・竹田邦夫・城所卓明：収縮低減剤を 用いたコ ンクリートの乾燥収縮性状, セメント技術年報, Vol. 37, 昭 58

6) 庄谷征美・杉田修一・菅原 隆 : 特殊混和剤によるコン クリートの収縮ひびわれ低減効果について, セメント技 術年報, Vol. 39, 昭 60

7）武田寿一・中根 淳・小柳光生・増田安彦: 鉄筋コンク リート外壁のひびわれに関する研究 (その1. 拘束実験), 日本建築学会大会学術講演梗概集, 昭 62

8）富田六郎・田中 智・本藤文明・竹中啓一：混和材料の 使用によるRC建築物のひびわれ低減効果, コンクリー 卜工学, Vol. 24, No. 5, 昭 61.5

9）杉山 雅-田中恭一・佐久田昌治・浦野敏晴: 乾燥収縮 を低減する混和剤を用いたコンクリートの基礎性状, 第 8 回コンクリート工学年次講演会講演論文集, 昭 61

10）小川 鑑- 夏井晋吉 - 戒田章弘・山口真樹： $R C$ 造建築 物におけるひび割れ防止対策の実際, 建築技術, 昭 62.8

11）佐久田昌治・浦野敏晴・和泉意登志・田中恭一・杉山 雅 : 高耐久性コンクリートの開発研究 (その 3 ), 日本建築 学会大会学術講演梗概集, 昭 61

12）大浜嘉彦・佐藤康彦：収縮低減剤を用いた 鋼繊維補強 ポ リマーセメントモルタルの 乾燥収縮挙動, 日本建築学会 大会学術講演梗概集, 昭 62 